\title{
Mutant GT198 in angiogenesis as a common origin of human prostate and bladder cancers
}

\author{
Liyong Zhang ${ }^{1}$, Yehai Liu², Liang Cheng ${ }^{3}$, Chengquan Zhao ${ }^{4}$, and Lan $\mathrm{Ko}^{1 *}$
}

${ }^{1}$ Georgia Cancer Center, Department of Pathology, Medical College of Georgia, Augusta University, Augusta, GA, USA

${ }^{2}$ Department of Otolaryngology-Head \& Neck Surgery, The First Affiliated Hospital, Anhui Medical University, Hefei, Anhui, China

${ }^{3}$ Department of Pathology and Laboratory Medicine, Indiana University School of Medicine, Indianapolis, IN, USA

${ }^{4}$ Department of Pathology, Magee-Womens Hospital, University of Pittsburgh, Pittsburgh, PA, USA

Running title: GT198 induces prostate and bladder cancers

*Address correspondence to: Lan Ko, MD/PhD, Augusta, GA, USA, Email: lan-ko@ outlook.com

Keywords: Oncogene GT198, somatic mutations, tumor stroma, prostate and bladder cancer.

\begin{abstract}
Prostate and bladder cancers are common cancers in men. It has been speculated that the high concomitant incidence of the two cancers is due to a potential shared cause underlying both cancers. In this report, we have identified a common cause of human prostate and bladder cancers as the mutant oncoprotein GT198 $(P S M C 3 I P)$. GT198 is a DNA repair factor and a steroid hormone receptor coactivator. GT198 has been previously shown to be mutated in angiogenic pericyte stem cells in solid tumor microenvironment. GT198 is also a direct protein target of chemo drugs paclitaxel and doxorubicin. Here we show, the GT198 gene is mutated with protein overexpression in tumor stroma of human prostate and bladder cancers. Affected stromal cells include angiogenic blood vessel pericyte stem cells, and vascular smooth muscle cell lineages including myofibroblasts in prostate and smooth muscle cells in bladder. In prostate cancers, $\mathrm{GT} 198^{+}$tumor stromal cells are associated with early stages of cancer with lower Gleason scores. In bladder cancers, the presence of angiogenesis and $\mathrm{GT}_{198}^{+}$stroma are associated with better progression-free survival in docetaxel-treated patients. Together, our evidence suggests that angiogenic pericyte stem
\end{abstract}

cells are initial lesions producing a mutant stroma carrying GT198 somatic mutations. Subsequently, mutant myofibroblasts promote adenocarcinomas in prostate and mutant smooth muscle cells promote urothelial carcinomas in bladder. Chemo drugs targeting to GT198 is more effective in early stages of cancers with $\mathrm{GT} 198^{+}$stromal cells. This study supports oncoprotein GT198 as a common cause and a drug target in human prostate and bladder cancers.

\section{INTRODUCTION}

Prostate cancer and bladder cancer are prevalent cancers in men. Clinical evidence has previously suggested that prostate and bladder cancers have higher concomitant incidence with a potential common pathway in tumor development (1-3).

In this study, we propose that a common molecular lesion exists as a shared origin of human prostate and bladder cancers. The responsible oncogene is called GT198 (gene symbol PSMC3IP), its protein product is also called Hop2 and TBPIP.

GT198 was initially identified as a transcriptional coactivator stimulating steroid hormone receptor-mediated gene activation $(4,5)$. 
GT198 directly binds to androgen, estrogen, and progesterone receptors (4), and stimulates CYP17 (cytochrome P450 17 $\alpha$ ) promoter (6). GT198 is potentially a master regulator in steroid hormone biosynthesis, which explains its oncogenic involvement in human breast (7), ovarian (6), and fallopian tube cancers (8). Prostate and bladder cancers are also hormone-dependent (9-13).

GT198 is also a DNA repair factor known as mammalian Hop2 or TBPIP $(8,14,15)$. GT198 is a DNA-binding protein dimer, binds to single- and double-stranded DNAs. It has been extensively characterized in DNA repair by participating in homologous DNA recombination (16-19). Since DNA repair factors are working as a protein complex, it should be no surprising for the extensive evidence that DNA repair factors including BRCA1 and BRCA2 contribute to the risk of prostate and bladder cancers (20), because GT198 is one of them in the DNA repair machinery.

It is important to note that the human GT198 gene is located at the chromosome 17q21 locus, 470 $\mathrm{Kb}$ proximal to the $B R C A 1$ gene $(21,22)$. The $17 \mathrm{q} 21$ locus has been repeatedly identified as a prostate cancer susceptibility gene locus by previous cancer genetic studies in familial prostate cancers (23-27). One early study correctly narrowed down the prostate cancer candidate gene to a less than $2 \mathrm{Mb}$ genomic interval between polymorphic marker D17S776 and BRCA1 (28), where GT198 is located. Evidence for the involvement of DNA repair genes in inherited prostate cancer is also significant $(29,30)$. Despite mounting evidence, GT198 was not revealed by cancer genetic studies alone in part due to its very small gene size, shadowed by $B R C A 1$, and carrying mostly splicing mutations rather than truncation mutations (see below).

The human GT198 gene has previously been shown to link to breast and ovarian cancer predisposition. Germline mutations in GT198 are identified in familial and early-onset human breast and ovarian cancer $(21,31)$, and in familial ovarian disease (32). Somatic mutations in GT198 are frequent and recurrent in sporadic breast (7), and ovarian cancers (6), where mutant GT198 protein leads to constitutive transcriptional activation $(8,21)$. In human breast cancer, the GT198 gene is mutated in the tumor stromal microenvironment. The mutant cells are pericyte stem cells and the descendent vascular smooth muscle cell lineage, including myoepithelial cells, fibroblasts, and adipocytes (7). Consistent with our findings, breast and prostate cancers share profound similarities in numerous aspects of their pathophysiology (12). Myoepithelial cells in breast are functionally equivalent to myofibroblasts in prostate. Both are contractile, hormone-responsive, and belong to the vascular smooth muscle cell lineage. When blood vessel pericytes were mutated in GT198 during angiogenesis $(6,7,33)$, stroma would become mutated consisting mutant stromal cells. Extensive evidence have already supported the important roles of stromal cells $(34,35)$, prostate cancerassociated fibroblasts (CAF) (36), and myofibroblasts (37), in tumorigenesis. Except that tumor stromal cells should no longer be considered normal, they are malignant carrying mutations prior to the alteration of epithelial cells. This may be common in human solid tumors (38), where pericyte stem cells are affected by overexpressing GT198 (33).

Taxanes including paclitaxel and docetaxel are chemotherapy drugs for prostate cancer. It is urgent to identify new therapeutic biomarkers in responders for effective treatment. Paclitaxel is lately found to be a direct GT198 inhibitor $(38,39)$. Thus, GT198 is a previously unanticipated target of taxane and needs to be evaluated as a new biomarker of taxane responsiveness in prostate cancer treatment.

In this report, we found that the GT198 gene is mutated with protein overexpression in human prostate and bladder cancer stroma. The earliest changes are angiogenic blood vessels, which consist $\mathrm{GT}_{198^{+}}$pericyte stem cells. Extensive stromal proliferation is found to follow angiogenesis. Myofibroblasts in prostate cancer and smooth muscle cells in bladder cancer are the most populous $\mathrm{GT}_{198}{ }^{+}$stromal cells, and carry somatic mutations in GT198. In prostate cancers, $\mathrm{GT}_{198}{ }^{+}$stromal cells are associated with early cancers with lower Gleason scores. In bladder cancers, GT198+ stroma but not GT $198^{+}$tumor is associated with better progression-free survival in docetaxel-treated patients. Our data together suggest that mutant GT198 ${ }^{+}$stromal cells are initial lesions in both prostate and bladder cancers before epithelial tumor cell development. Docetaxel targeting to GT $198^{+}$stroma with angiogenesis may result in higher treatment efficacy. This is a first study to support oncoprotein GT198 as a common 
cause as well as a treatment biomarker in human prostate and bladder cancers.

\section{RESULTS}

\section{GT198 overexpression in human prostate and} bladder tumor stroma

We have previously identified cytoplasmic GT198 expression as precursor lesions in tumor stroma of various human solid tumors $(6,7,33)$. In this study, focusing on GT198 in human prostate and bladder cancers, we analyzed GT198 expression by immunohistochemistry in 65 cases of tumor tissue microarrays and 15 cases of tumor sections of prostate cancers, and 17 cases of tumor sections of bladder cancers (Table 1-4).

In human prostate stroma with angiogenesis before tumor cells appear, GT198 is strongly expressed in blood vessel pericytes in capillaries (Figure 1A). GT198 is also found in smooth muscle cells in larger blood vessels (Figure 1B-C), and in proliferative myofibroblasts of the prostate stroma at the early stages of cancer development (Figure 1D). GT198+ myofibroblasts continue to accumulate and become fibrous GT198 ${ }^{+}$tumor stroma (Figure 1E). More than half of the epithelial tumors are negative in GT198 expression, with diluted GT198 ${ }^{+}$myofibroblasts among them. Some evolve into GT198 ${ }^{+}$tumors (Figure 1F-H). Normal GT198- blood vessels can also be found in tumor tissues.

With GT198 as a clear marker, it appears that $\mathrm{GT}_{198^{+}}$vessel pericytes as stem cells have produced $\mathrm{GT}_{198^{+}}$vascular smooth muscle cell lineages including myofibroblasts and blood vessel smooth muscles. These prostate stroma lesions together induce epithelial proliferation, given that myofibroblasts dictate prostate epithelial cell growth (13).

A very similar scenario can be found in human bladder cancers (Figure 2). In contrast to normal GT198- blood vessels (Figure 2A), GT198 ${ }^{+}$ angiogenic capillaries are clustered and underlie the urothelial layer (Figure 2B). The positive vessels further mature into larger vessels (Figure 2C-D), and the same vascular smooth muscle cell lineage eventually creates GT $198^{+}$smooth muscle layers of the bladder (Figure 2E). The fibrous GT198 stroma can be predominant in the tissue slides, which permitted detection of GT198 somatic mutations (see below). The stromal lesions are multifocal, derived from angiogenesis, and likely drive the growth of urothelial carcinomas (Figure 2F). Tumor cells can be either GT198+ or GT198(Table 4). It is currently unclear whether GT198+ stem or progenitor cells could differentiate into GT198+ urothelial carcinomas.

$\mathrm{GT}{ }^{+}{ }^{+}$stromal myofibroblasts are associate with low Gleason scores in prostate cancers

The expression of GT198 in prostate cancers was examined by immunohistochemical staining. The overall positive rates in prostate cancers are high, $97.5 \%(39 / 40)$ in a high quality tumor microarray, $68 \%(17 / 25)$ in a low quality microarray, and $93.3 \%(14 / 15)$ in prostate tumor sections (Table 1-3). In 9 cases of tumor adjacent stroma, traditionally called adjacent normal, GT198 is expressed in all cases (Table $\mathbf{1}$ and Figure 3A). Because the size of tissue is much smaller in microarrays than tissue sections which contain more stromal areas, GT198 ${ }^{+}$myofibroblasts positive rate is found higher in tissue sections at 86.6\% (Figure 3A). When Gleason scores were analyzed with the GT198 expression, GT198+ stroma is more associated with cases with low Gleason scores than the GT198 stroma, but GT198+ tumors have no significant association with Gleason scores than the GT198- tumors (Figure 3C). Data suggest that prostate cancers at the early stages contain more GT198 ${ }^{+}$myofibroblasts.

$\mathrm{GT}{ }^{+}$stroma is a predictive biomarker in docetaxel treatment of human bladder cancers

GT198 is expressed in bladder cancers with an overall positive rate of 76.4\% (14/17) (Table 4 and Figure 3B). GT198 can be highly expressed in bladder stroma before the evidence of tumor (T0 in cases of B1, B4 and B7) based on the pTNM staging (Table 4), although statistical significance cannot be determined due to the small sample size analyzed. B1 and B4 cases also carry GT198 mutations (Table 4 and Figure 5). The data is consistent with GT198 ${ }^{+}$stroma as very early lesions in bladder cancer (Figure 2B).

Clinical information of bladder cancer patients (B1-B17) is shown in Table 4. The FFPE slides were immunohistochemical stained with GT198 to determine GT198+ myofibroblasts $(52.9 \%, 9 / 17)$, GT198+ tumor cells $(47 \%, 8 / 17)$, and the presence of angiogenesis $(41.1 \%, 7 / 17)$ (Table 4). The 
presence of angiogenesis is determined by the presence of blood vessel clusters. Adjacent slides of 15 cases (B1-B15) were Sanger sequencing analyzed for $G T 198$ mutations with a positive rate of $40 \%$ (6/15). Progression-free survival was analyzed by the Kaplan-Meier methods. The results show that GT198+ stroma but not GT198+ tumor is significantly associated with better progressionfree survival, $\quad P=0.0066, \quad \mathrm{HR}=0.1958$ (95\% CI $=0.03-0.08)$ in docetaxel-treated bladder cancer patients (Figure 4A-B). Tumor angiogenesis in stroma is also associated with better progression-free survival, $P=0.027, \quad H R=0.255$ (95\% CI=0.06-0.84) (Figure 4C). In most cases with $\mathrm{GT}_{198^{+}}$stroma, angiogenesis is present (Table 4). This is a first study to suggest that GT198 is a predictive biomarker in docetaxel treatment of bladder cancer. Larger sample size analysis in the future will help to validate the current finding.

$\mathrm{GT198}^{+}$prostate and bladder cancer stroma harbors GT198 somatic mutations

GT198 expression in stromal blood vessels accompanied by angiogenesis is a strong indicator for the presence of GT198 somatic mutations in breast, ovarian, and fallopian tube cancers (6-8). Here, we carried out Sanger sequencing analysis of selected prostate and bladder cancers spanning previously identified GT198 mutation hotspots (Figure 5) $(7,8)$. Because stroma proliferation is massive in prostate and bladder cancers, microdissection was not required, and the samples were obtained using GT198-stained adjacent slides to locate the GT $198^{+}$stroma or tumor.

In four cases of prostate cancer analyzed (Table 3), three cases (P1-P3) carry GT198 somatic mutations with a positive rate of 75\% (3/4) (Figure 5A-B). Multiple mutations are present in P1 and P2 cases. The $\mathrm{P} 1$ prostate cancer stroma carries six GT198 mutations (Figure 5B), has a Gleason score of 6 (Table 3), contains mostly $\mathrm{GT} 198^{+}$stroma rather than tumor, and has abundant GT198+ angiogenic vessels (Supplemental Figure S1). This is a typical case that the early stage prostate cancer stroma has multifocal lesions with different GT198 somatic mutations.

In 15 cases of bladder cancers analyzed, six cases carry GT198 mutations (40\%, 6/15). Mutations can be found in both GT $198^{+}$stroma and bladder tumors (Table 4 and Figure 5C).
Most GT198 point mutations identified are newly found in this study, although a few mutations are previously known in other cancers (Figure 5A). These mutations are likely deregulating alternative splicing of GT198 as we previously proposed (8), since most of them are not truncating mutations or affecting coding regions (Figure 5A).

Because conventional Sanger sequencing requires a mutant cell population carrying the same mutation to yield enough DNA to be detectable, our finding indicates that multifocal and clonally expanded mutant cells are present in prostate and bladder cancers. Together, our results show that high frequency of GT198 somatic mutations are present in GT198 ${ }^{+}$tumor stroma and tumor cells in human prostate and bladder cancers.

\section{DISCUSSION}

GT198 is an excellent biomarker to reveal the origin of prostate and bladder cancer from their tumor stroma for several reasons. Previous evidence has shown that GT198 is a stem cell regulator affecting blood vessel pericyte stem cells in tumor angiogenesis (33). GT198 is an oncogene producing mutant tumor stroma driving epithelial cell growth $(6,7)$. GT198 is a nuclear receptor coactivator (4), stimulating hormone-associated target genes which are critical in prostate and bladder cancer development. GT198 is a DNA repair factor $(14,19)$, permitting hypermutation to occur when GT198 itself is functionally defective, similarly to p53. In fact, GT198 and p53 share profound similarities in their structural and functional properties (40-42), and both carry abundant splicing mutations.

A model of GT198 in human prostate and bladder cancer can be proposed in view of historical evidence as well as our current findings (Figure 6). Pericytes are stem cells located on capillaries of blood vessels (43), producing vascular smooth muscle cell lineages including myofibroblasts and smooth muscle cells in prostate and bladder. When the GT198 gene is mutated in pericytes with GT198 overexpression, it causes angiogenesis (33), and produces $\mathrm{GT}_{198}{ }^{+}$stroma (Figure 1-2). GT198 continues to mutate since DNA repair is defective. Hypermutation results in GT198 spicing defects (8), and GT198 protein constitutive activation (7). As a transcriptional coactivator, GT198 may over 
stimulate steroid hormone receptor-mediated target genes in prostate and bladder, and in turn to induce proliferation of stromal cells and epithelial or urothelial cells (Figure 6). This mechanism is likely shared in prostate and bladder cancers. As a biomarker of cancer-initiating stromal cells, GT198 protein may also serve as a drug target (Figure 4). This model predicts that GT198 is a common cause and a drug target for both prostate and bladder cancers.

Although high frequency GT198 mutations are present in prostate and bladder cancers, it is current unclear whether GT198 overexpression is always due to its mutations. Not all GT198 ${ }^{+}$prostate and bladder samples are found mutation positive (Table 3-4), however, these could be due to technical reasons. We have only sequenced the two mutation hotspots not the entire GT198 gene, since DNAs are more fragmented in the FFPE tissues. If a mutation were located outside the hotspots, we would miss to detect. Additionally, scattered mutant stromal cells within outgrowing mutation-negative tumor cells would not be detectable without deep sequencing.

GT198 protein is a predictive biomarker so that it can be a drug target. Paclitaxel was previously found as a direct GT198 inhibitor (39), and its analog docetaxel would inhibit GT198 ${ }^{+}$stromal cells to achieve effective therapy (Figure 4). In the future, better GT198 inhibitors can be tested as potential drugs for the treatment of prostate and bladder cancers. As a predictive biomarker, the association of GT198 expression with androgen dependence also needs to be investigated to aid the decision in therapy. In addition, whether GT198 is responsible for familial prostate cancer can now be analyzed in familial prostate cancer cohorts with segregation by directly sequencing the human GT198 gene.

In summary, we have found high frequency GT198 somatic mutations and GT198 oncoprotein overexpression in tumor stroma of human prostate and bladder cancers. GT $198^{+}$tumor stromal cells include pericyte stem cells, myofibroblasts in prostate cancer, and smooth muscle cells in bladder cancer. Mutant GT $198^{+}$stromal cells appear at the initial stages of tumor development, resulting in a mutant stroma driving epithelial cell growth. In bladder cancers, the presence of angiogenesis and GT198 ${ }^{+}$stroma are associated with better progression-free survival in docetaxel-treated patients. This implies targeting GT198 at the early stages of cancer is more therapeutic effective. Together, our results suggest the presence of a common origin of both human prostate and bladder cancers, in which mutant GT $198^{+}$stroma serves as an epicenter of the tumor development. GT198 protein may thus be a therapeutic target in the treatment of human prostate and bladder cancers.

\section{ACKNOWLEDGEMENTS}

We thank Dr. Nahid F. Mivechi for providing reagents. This work was supported in part by the Georgia Cancer Coalition Distinguished Cancer Scholar Award to L.K.

\section{CONFLICT OF INTERESTS}

LK is an inventor of GT198 patents. 

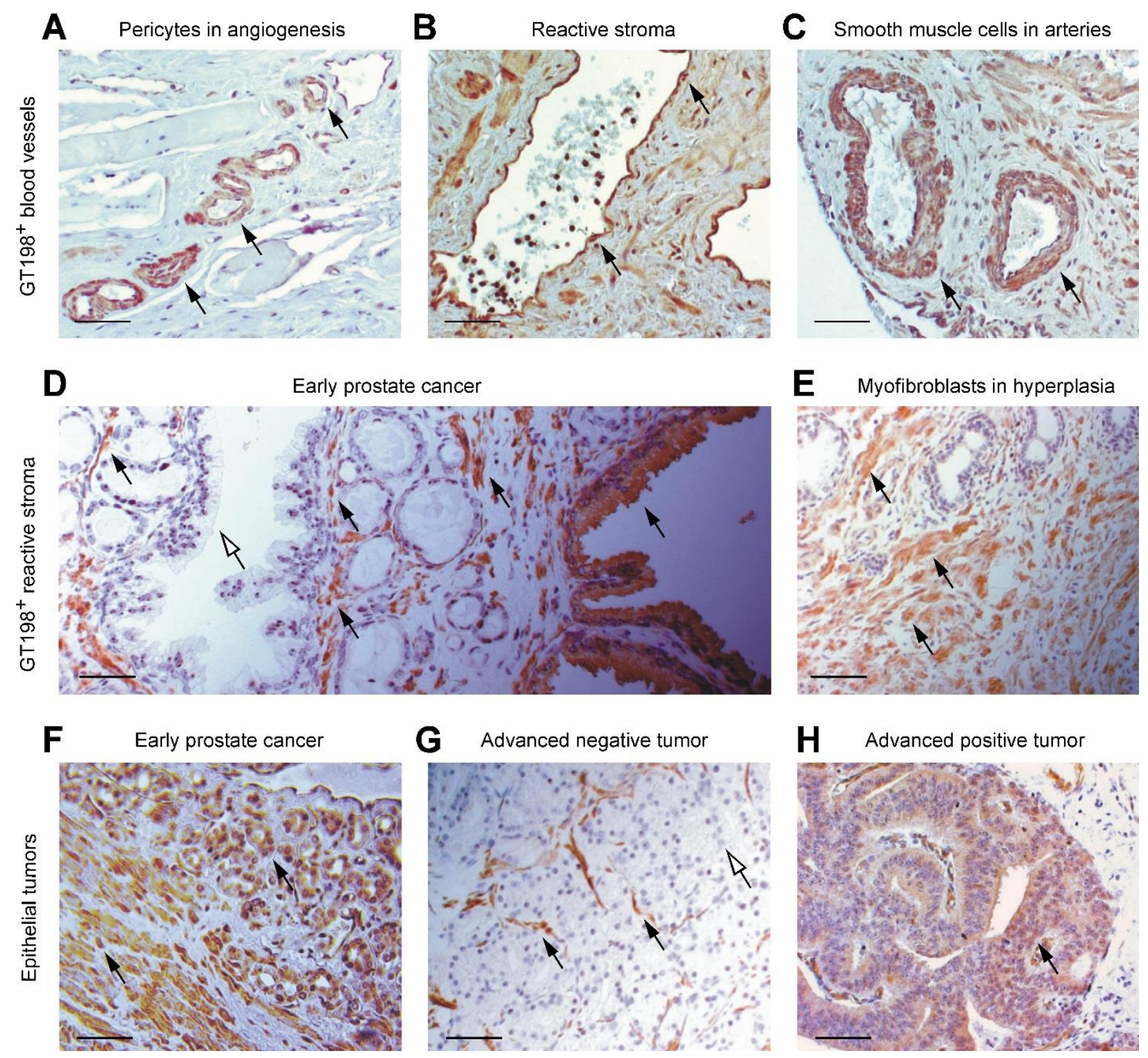

Figure 1. GT198 expression in human prostate cancers. Immunohistochemical staining of GT198. (A) At the early stage of prostate cancer development, GT198 is expressed in capillaries of tumor microenvironment with angiogenesis. Pericytes and vascular smooth muscle cells are GT198 ${ }^{+}$. (B-C) In angiogenic prostate cancer stroma, both veins and arteries are GT198 ${ }^{+}$surrounded by proliferative fibroblasts and myofibroblasts. (D) In prostate cancers at the early stages, epithelium overgrowth is underlain by GT198 myofibroblasts. Epithelial cells are often negative in GT198 expression except some clonal expanded clusters can be GT198 ${ }^{+}$. (E) The proliferative and hyperplastic tumor stroma is populated by abundant $\mathrm{GT}_{198^{+}}$myofibroblasts. (F) Early stage $\mathrm{GT}_{198^{+}}$tumor cells and myofibroblasts. (G-H) In advanced prostate tumors, GT198 ${ }^{+}$myofibroblasts are diluted by the overgrowth of epithelial cells, either negative or positive in GT198 expression. Black and white arrows indicate GT198 ${ }^{+}$or GT198 cells, respectively. Sections were counter-stained with hematoxylin. Scale bars $=100 \mu \mathrm{m}$. 


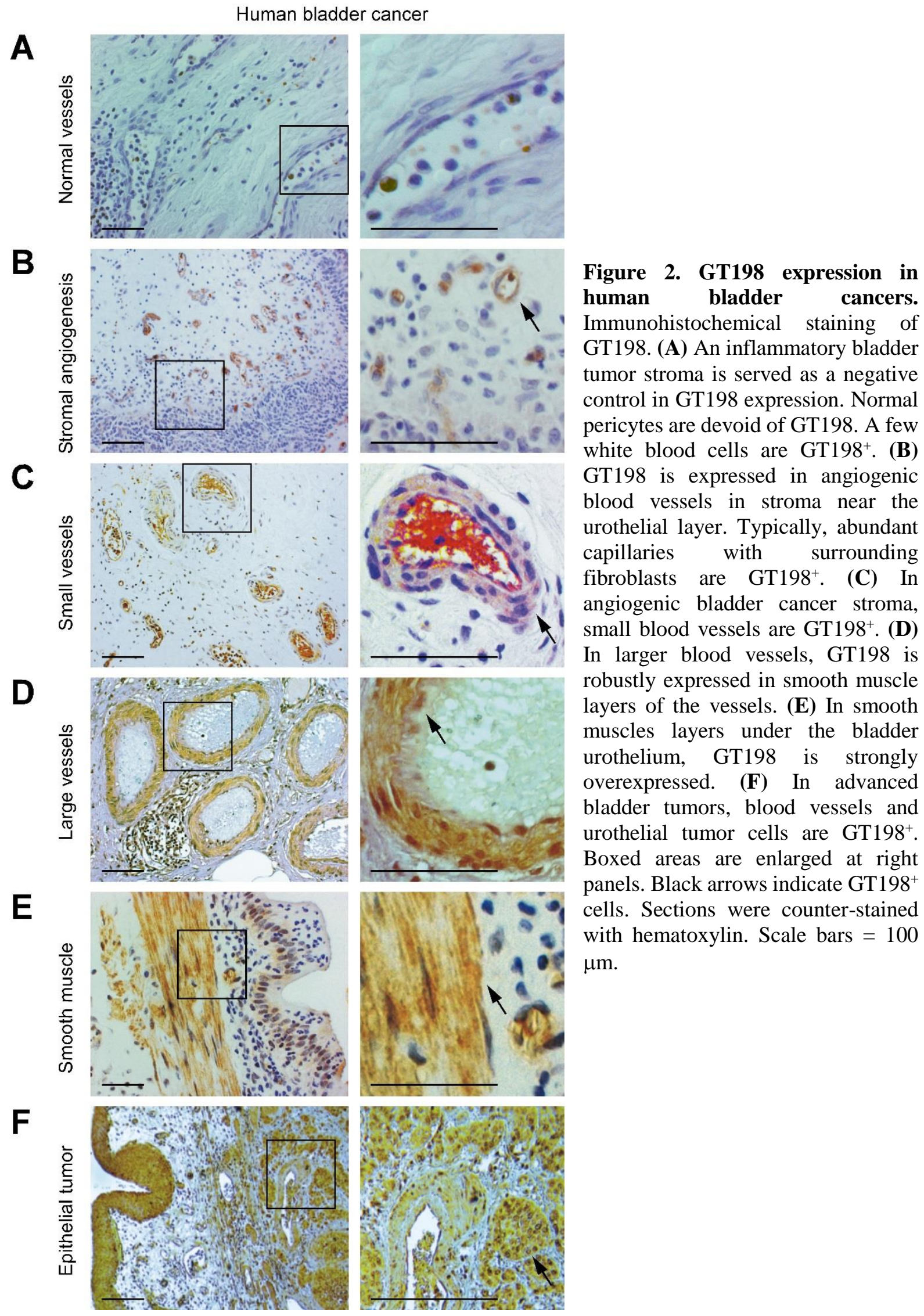


A

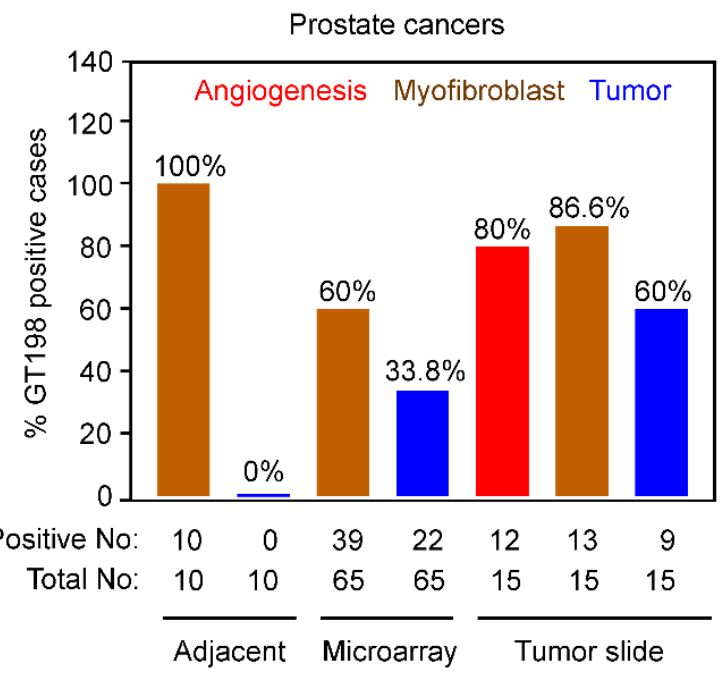

B

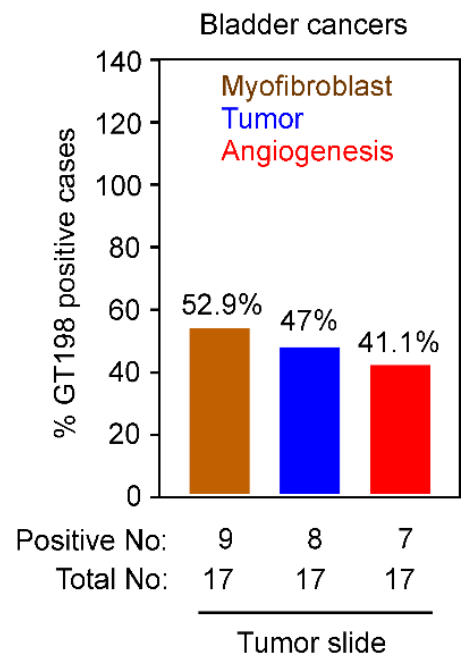

\section{C}

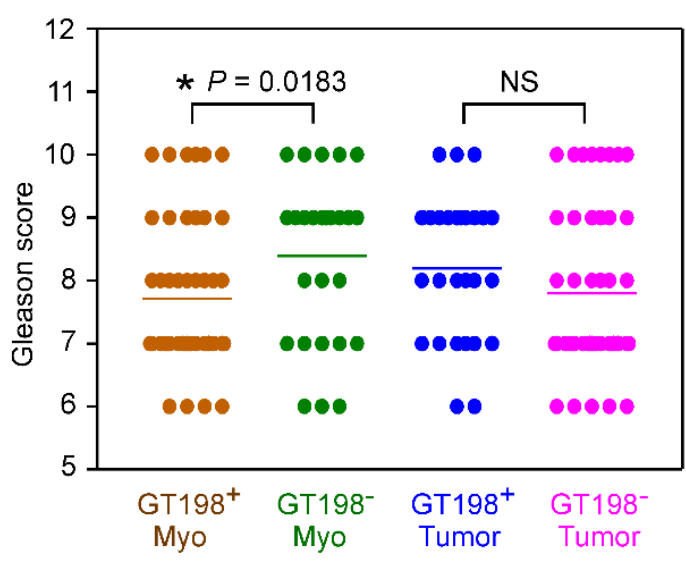

Figure 3. GT198 expression in prostate and bladder cancers. Immunohistochemical staining of GT198 in 65 cases of prostate tumor tissue microarray, 15 cases prostate tumor slides, and 17 cases of bladder tumor slides (Table 1-4). (A) Percent of GT198+ cases in each type of prostate cancer tissues: pericytes in angiogenic stroma, myofibroblasts, and epithelial tumor cells. (B) Percent of GT198 ${ }^{+}$cases in each type of bladder cancer tissues. (C) Comparison of Gleason scores in prostate cancers with GT198 ${ }^{+}$or GT198myofibroblasts and tumor cells. GT198 ${ }^{+}$myofibroblasts have significant association with the cases having lower Gleason scores, which are early stages of cancers. ${ }^{*} P<0.05$. The Gleason sores between $\mathrm{GT} 198^{+}$and GT198- tumor cells are insignificantly different. $P>0.05$ (NS). 

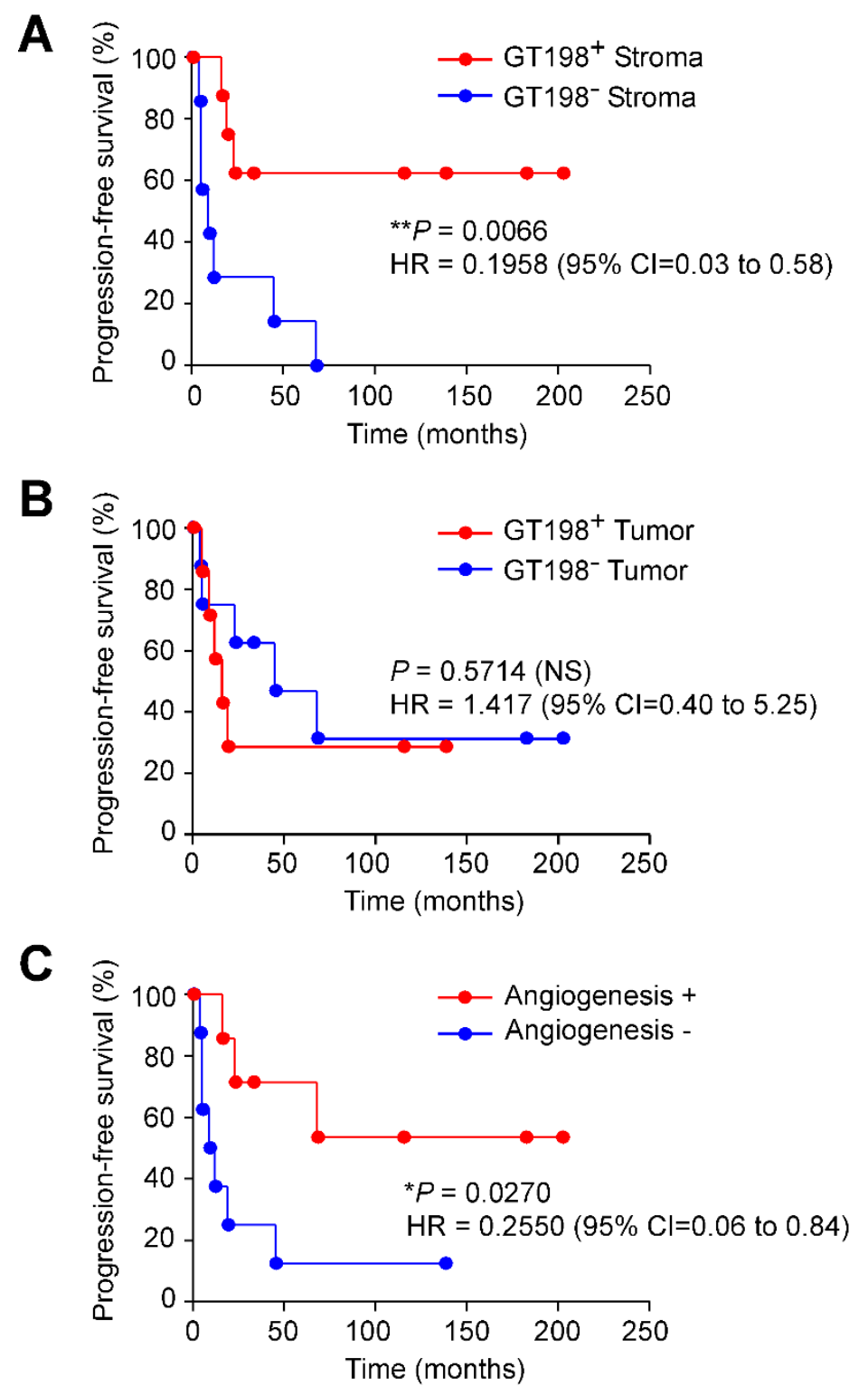

Figure 4. GT198 ${ }^{+}$stroma and angiogenesis are associated with significantly better progression-free survival in docetaxel-treated bladder cancer patients. Clinical information of docetaxel-treated 15 bladder cancer patients is shown in Table 4. The 15 FFPE slides were immunohistochemical stained with GT198 for analyzing myofibroblasts and tumor cells. Angiogenesis is determined by the presence of blood vessel clusters. Progression-free survival months and last follow up status are analyzed by the KaplanMeier method. (A) In docetaxel-treated bladder cancers, GT198 expression in stroma is significantly associated with better progression-free survival. (B) GT198 expression status in tumor cells is not associated with the progression-free survival. (C) Angiogenesis in tumor stroma, disregarding GT198 expression, is associated with significantly better progression-free survival. $P$ values are calculated by $\log$ rank test. $* P<0.05$. $* * P<0.01 . P>0.05$, not significant (NS). 

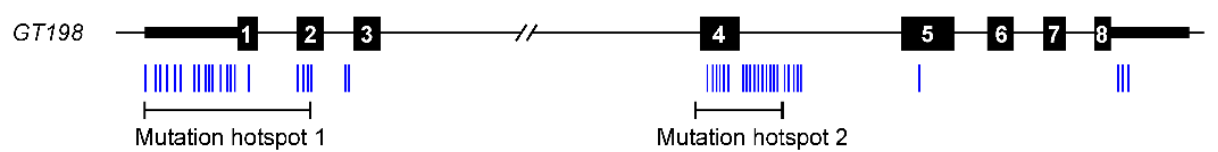

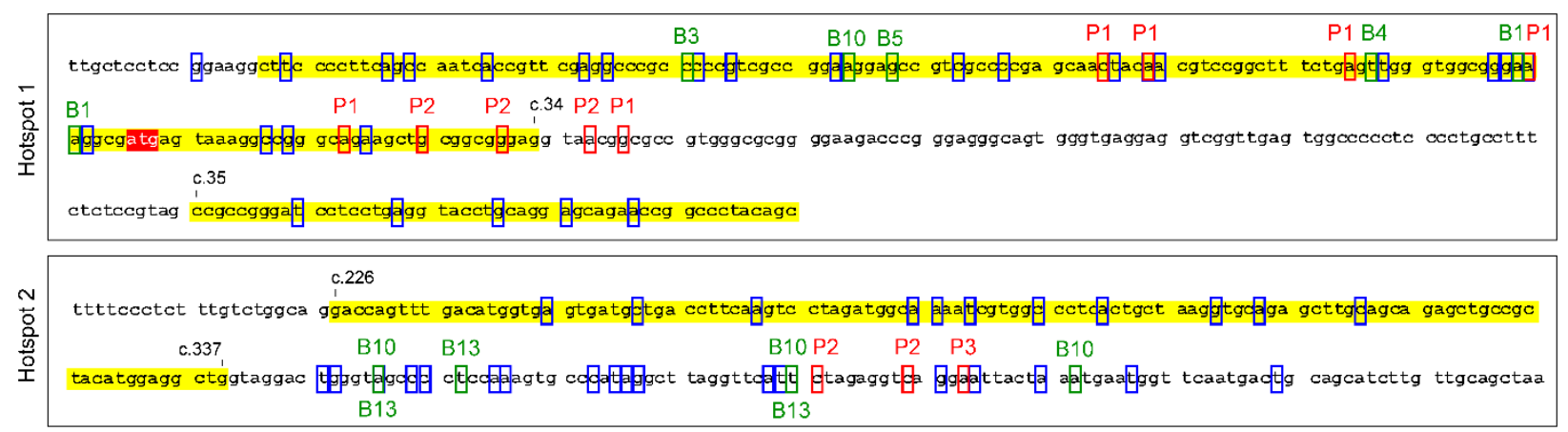

B Prostate Cancer Mutations

P1: c. $-41 \mathrm{C}>\mathrm{T} ; \mathrm{C}-37 \mathrm{~A}>\mathrm{T} ; \mathrm{C} .-21 \mathrm{~A}>\mathrm{T} ; \mathrm{C} .-6 \mathrm{~A}>\mathrm{T} ; \mathrm{c} .18 \mathrm{~A}>\mathrm{T} ; \mathrm{c} .34+7 \mathrm{G}>\mathrm{T}$.

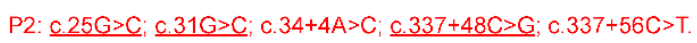

P3: c. $337+60 \mathrm{~A}>\mathrm{C}$

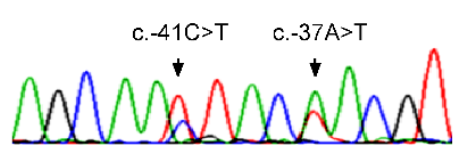

$A G C A A C T A C A A C G T$

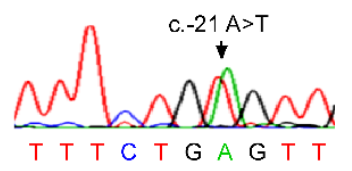

C Bladder Cancer Mutations

B1: $C .-5 A>T ; C .-7 A>T$.

B3: $C .-75 \mathrm{C}>\mathrm{T}$.

B4: $C .-19 T>C$

B5: $\mathrm{C} .-58 \mathrm{G}>\mathrm{T}$

B10: c. $-62 A>T ; c .337+13 A>G ; c .337+47 T>C ; c .337+69 A>C$ B13: $\underline{\underline{c} .337+13 A>G ; c .337+19 T>A ; \underline{c} .337+47 T>C \text {. }}$

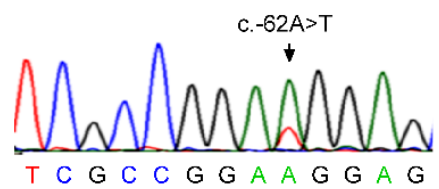

Figure 5. $\mathrm{GT198}^{+}$prostate and bladder cancer stroma harbors GT198 somatic mutations. (A) A diagram of the human GT198 gene is depicted with numbered boxes as exons and lines as introns. The two mutation hotspots are indicated. Blue bars represent GT198 germline and somatic mutations from previous studies $(6-8,21)$. Nucleotide sequences of the two mutation hotspots are shown with exons in yellow and start codon in red. Previously identified GT198 mutations in cancer are indicated in blue boxes. Mutations identified from prostate cancers in this study are indicated in red boxes (P1-P3), and from bladder cancers are indicated in green boxes (B1, B3-B5, B10, B13) (Table 3-4). Mutation numbering is based on the cDNA reference sequence. (B) Mutations in prostate cancers with representative sequence trace chromatograms. (C) Mutations in bladder cancers with representative sequence trace chromatograms. Nucleotide changes in somatic point mutations are indicated by arrows with wild type sequences shown below. Most mutations are newly identified in this study except that the same mutations found in other cancers from previous studies are underlined. 


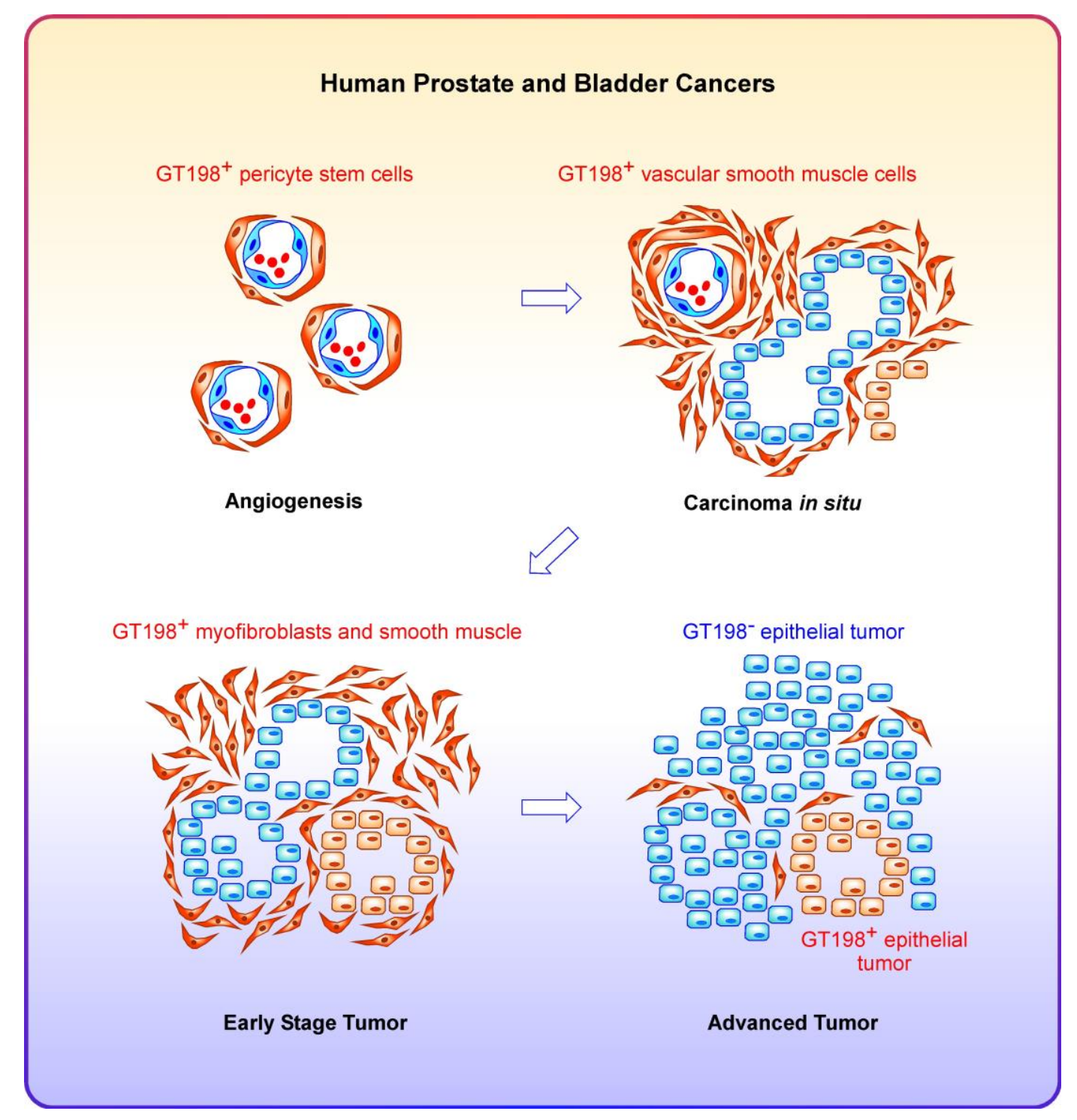

Figure 6. A common origin of human prostate and bladder cancers. A model of oncoprotein GT198 in human prostate and bladder cancer development. Pericytes are stem cells producing vascular smooth muscle cell lineages including blood vessel smooth muscle cells, fibroblasts, myofibroblasts, and smooth muscles in prostate and bladder. When the GT198 gene is mutated in angiogenic pericytes with overexpression of GT198, GT198 ${ }^{+}$descendent stromal cells create a mutant reactive stroma propelling epithelial cell growth. Epithelial cells can be either GT198 ${ }^{+}$or GT198. At the advanced stages of cancer development, GT198 ${ }^{+}$stromal cells are outgrown by epithelial or urothelial tumor cells. Docetaxel has better treatment efficacy in cancers with GT198+ stroma (Figure 4), suggesting that it is more effective to target to the origin of cancer, which is shared in human prostate and bladder cancers. 
bioRxiv preprint doi: https://doi.org/10.1101/726679; this version posted August 6, 2019. The copyright holder for this preprint (which was not certified by peer review) is the author/funder, who has granted bioRxiv a license to display the preprint in perpetuity. It is made available under aCC-BY 4.0 International license.

Table 1. GT198 expression in prostate tumor tissue microarray (Novus Biologicals NBP2-30169, IMH-303) Overall GT198 positive rate $=97.5 \%(39 / 40)$

\begin{tabular}{|c|c|c|c|c|c|c|c|}
\hline $\begin{array}{l}\text { Core } \\
\text { No }\end{array}$ & Age & Diagnosis & Gleason Score & pTNM & Stage & $\begin{array}{c}\text { GT198+ } \\
\text { Myofibroblast }\end{array}$ & $\begin{array}{l}\text { GT198+ } \\
\text { Tumor }\end{array}$ \\
\hline 1 & 60 & adenocarcinoma & 9 & T3bNOMO & III & & + \\
\hline 2 & 64 & adenocarcinoma & 7 & T2cNOMO & $\mathrm{IIB}$ & + & \\
\hline 3 & 71 & adenocarcinoma & 9 & T3bNOMO & III & & + \\
\hline 4 & 64 & adenocarcinoma & 10 & T3aNOMO & III & \pm & + \\
\hline 5 & 59 & adenocarcinoma & 9 & T3bNOMO & III & + & \\
\hline 6 & 65 & adenocarcinoma & 8 & T3bNOMO & III & & + \\
\hline 7 & 73 & adenocarcinoma & 7 & T2cNOMO & $\mathrm{IIB}$ & + & \\
\hline 8 & 69 & adenocarcinoma & 7 & T2cNOMO & IIB & + & \\
\hline 9 & 62 & adenocarcinoma & 7 & T2cNOMO & IIB & + & \\
\hline 10 & 66 & adenocarcinoma & 9 & T3bNOMO & III & & + \\
\hline 11 & 60 & adenocarcinoma & 9 & T3bNOMO & III & + & \\
\hline 12 & 66 & adenocarcinoma & 7 & T3aNOMO & III & + & \\
\hline 13 & 70 & adenocarcinoma & 7 & T3bNOMO & III & + & \\
\hline 14 & 65 & adenocarcinoma & 9 & T3bNOMO & III & + & \\
\hline 15 & 67 & adenocarcinoma & 9 & T3bN1M0 & III & & + \\
\hline 16 & 69 & adenocarcinoma & 7 & T3bNOMO & III & + & \\
\hline 17 & 63 & adenocarcinoma & 9 & T3aN1M0 & III & & + \\
\hline 18 & 69 & adenocarcinoma & 7 & T3aNOMO & III & + & \\
\hline 19 & 70 & adenocarcinoma & 7 & T3aNOMO & III & + & \\
\hline 20 & 58 & adenocarcinoma & 9 & T3bNOMO & III & + & + \\
\hline 21 & 58 & adenocarcinoma & 7 & T3bNOMO & III & + & \\
\hline 22 & 71 & adenocarcinoma & 7 & T2cNOMO & IIB & + & \\
\hline 23 & 70 & adenocarcinoma & 7 & T3bNOMO & III & + & + \\
\hline 24 & 59 & adenocarcinoma & 6 & T2bNOMO & IIA & + & \\
\hline 25 & 63 & adenocarcinoma & 9 & T3bNOMO & III & + & \\
\hline 26 & 72 & adenocarcinoma & 9 & T3bNOMO & III & & + \\
\hline 27 & 66 & adenocarcinoma & 8 & T3bNOMO & III & + & \\
\hline 28 & 70 & adenocarcinoma & 6 & T3bNOMO & III & & \\
\hline 29 & 70 & adenocarcinoma & 7 & T2cNOMO & $\mathrm{IIB}$ & + & + \\
\hline 30 & 68 & adenocarcinoma & 8 & T3bNOMO & III & + & \\
\hline 31 & 63 & adenocarcinoma & 10 & T3bNOMO & III & & + \\
\hline 32 & 57 & adenocarcinoma & 7 & T3bNOMO & III & + & \\
\hline 33 & 72 & adenocarcinoma & 8 & T2cNOMO & IIB & & + \\
\hline 34 & 70 & adenocarcinoma & 8 & T3bNOMO & III & + & \\
\hline 35 & 75 & adenocarcinoma & 9 & T3bNOMO & III & & + \\
\hline 36 & 62 & adenocarcinoma & 9 & T3bNOMO & III & & + \\
\hline 37 & 63 & adenocarcinoma & 9 & T3bNOMO & III & & + \\
\hline 38 & 53 & adenocarcinoma & 9 & T3bNOMO & III & & + \\
\hline 39 & 63 & adenocarcinoma & 8 & T3bNOMO & III & + & + \\
\hline \multirow[t]{2}{*}{40} & 44 & adenocarcinoma & 7 & T3bNOMO & III & + & \\
\hline & & & & & & $65 \%$ & $45 \%$ \\
\hline 41 & 69 & adjacent (match of \#8) & . & & . & + & \\
\hline 42 & 62 & adjacent (match of \#9) & . & . & . & + & \\
\hline 43 & 66 & adjacent (match of \#12) & . & . & . & + & \\
\hline 44 & 65 & adjacent (match of \#14) & . & . & . & + & \\
\hline 45 & 69 & adjacent (match of \#18) & . & . & . & + & \\
\hline 46 & 70 & adjacent (match of \#19) & . & . & . & + & \\
\hline 47 & 70 & adjacent (match of \#29) & . & . & . & + & \\
\hline 48 & 63 & adjacent (match of \#31) & . & & . & + & \\
\hline \multirow[t]{2}{*}{49} & 44 & adjacent (match of \#40) & . & . & . & + & \\
\hline & & & & & & $100 \%$ & $0 \%$ \\
\hline
\end{tabular}




\begin{tabular}{|c|c|c|c|c|c|c|c|}
\hline \multicolumn{8}{|c|}{$\begin{array}{l}\text { Table 2. GT198 expression in prostate tumor tissue microarray (US Biomax PR1001) } \\
\text { Overall GT198 positive rate }=68 \%(17 / 25)\end{array}$} \\
\hline $\begin{array}{l}\text { Core } \\
\text { No }\end{array}$ & Age & Diagnosis & $\begin{array}{l}\text { Gleason } \\
\text { Score }\end{array}$ & pTNM & Stage & $\begin{array}{c}\text { GT198+ } \\
\text { Myofibroblast }\end{array}$ & $\begin{array}{l}\text { GT198+ } \\
\text { Tumor }\end{array}$ \\
\hline 1 & 70 & adenocarcinoma & 7 & T3NOMO & III & & + \\
\hline 2 & 64 & adenocarcinoma & 6 & T2aNOMO & II & + & \\
\hline 3 & 78 & adenocarcinoma & 7 & T4N1M1b & IV & & \\
\hline 4 & 65 & adenocarcinoma & 8 & T2NOMO & II & + & \\
\hline 5 & 75 & adenocarcinoma & 6 & T4N1M1 & IV & & \\
\hline 6 & 70 & adenocarcinoma & 7 & T2N1M1c & IV & & \\
\hline 7 & 62 & adenocarcinoma & 7 & T3N1M1h & IV & & \\
\hline 8 & 76 & adenocarcinoma & 7 & T2aNOMO & II & + & \\
\hline 9 & 62 & adenocarcinoma & 10 & T2NOMO & II & \pm & \\
\hline 10 & 64 & adenocarcinoma & 9 & T2NOMO & II & + & \\
\hline 11 & 65 & adenocarcinoma & 7 & T2NOMO & II & & \pm \\
\hline 12 & 82 & adenocarcinoma & 10 & T3N2M1 & IV & + & \\
\hline 13 & 66 & adenocarcinoma & 7 & T3aNOMO & III & + & \\
\hline 14 & 76 & adenocarcinoma & 10 & T3N1M1b & IV & \pm & \\
\hline 15 & 76 & adenocarcinoma & 7 & T2aNOMO & II & + & \\
\hline 16 & 73 & adenocarcinoma & 10 & T3N1M1 & IV & & + \\
\hline 17 & 60 & adenocarcinoma & 7 & T3N1M0 & IV & + & \\
\hline 18 & 73 & adenocarcinoma & 10 & T4N1M1c & IV & \pm & \\
\hline 19 & 77 & adenocarcinoma & 7 & T2NOMO & II & + & \\
\hline 20 & 55 & adenocarcinoma & 10 & T2NOMO & II & + & \\
\hline 21 & 60 & adenocarcinoma & 10 & T2NOMO & II & & \\
\hline 22 & 87 & adenocarcinoma & 10 & T2NOMO & II & & \\
\hline 23 & 81 & adenocarcinoma & 9 & T2aNOMO & III & & + \\
\hline 24 & 75 & adenocarcinoma & 10 & T2N1M1C & IV & & \\
\hline \multirow[t]{2}{*}{25} & 80 & adenocarcinoma & 6 & T4N1M1c & IV & & \\
\hline & & & & & & $52 \%$ & $16 \%$ \\
\hline
\end{tabular}

Table 1-2. GT198 expression in human prostate tumor tissue microarrays. Two prostate tumor tissue microarrays (40 cases in NBP2-30169/IMH-303, core diameter $2.0 \mathrm{~mm}$, thickness $4 \mu \mathrm{M}$; and 25 cases in PR1001, core diameter $1.0 \mathrm{~mm}$, thickness $5 \mu \mathrm{M}$.) were immunohistochemically stained with GT198 and analyzed for the presence of GT198 ${ }^{+}$ myofibroblasts and GT198+ tumor cells. The GT198 negative cases are shaded in light blue. Percent of positive cases in total and percent of positive cases in myofibroblasts or tumor cells are listed in blue. In NBP2-30169, there are nine cases of matched adjacent tissues absent of tumor cells but containing positive tumor stroma. The quality of the NBP2-30169 section is much higher than the PR1001, in which immunohistochemical staining may be failed in some negative cases. 


\begin{tabular}{|c|c|c|c|c|c|c|c|}
\hline \multicolumn{8}{|c|}{$\begin{array}{l}\text { Table 3. GT198 expression in prostate tumor slides } \\
\text { Overall GT198 positive rate }=93.3 \%(14 / 15)\end{array}$} \\
\hline $\begin{array}{l}\text { Case } \\
\text { No }\end{array}$ & Age & Diagnosis & $\begin{array}{l}\text { Gleason } \\
\text { Score }\end{array}$ & $\begin{array}{c}\text { GT198+ } \\
\text { Blood vessel }\end{array}$ & $\begin{array}{c}\text { GT198+ } \\
\text { Myofibroblast }\end{array}$ & $\begin{array}{l}\text { GT198+ } \\
\text { Tumor }\end{array}$ & $\begin{array}{c}\text { GT198 } \\
\text { Mutation }\end{array}$ \\
\hline $\mathrm{P} 1$ & 80 & adenocarcinoma & 6 & + & + & + & 6 \\
\hline $\mathrm{P} 2$ & 85 & adenocarcinoma & 8 & & + & + & 5 \\
\hline P3 & 92 & adenocarcinoma & 9 & + & + & & 1 \\
\hline $\mathrm{P} 4$ & 90 & adenocarcinoma & 8 & + & & & 0 \\
\hline P5 & 57 & adenocarcinoma & 8 & + & + & + & n.a. \\
\hline P6 & 60 & adenocarcinoma & 7 & + & + & + & n.a. \\
\hline P7 & 63 & adenocarcinoma & 7 & + & + & + & n.a. \\
\hline P8 & 63 & adenocarcinoma & 8 & + & + & + & n.a. \\
\hline P9 & 52 & adenocarcinoma & 7 & + & + & + & n.a. \\
\hline P10 & 63 & adenocarcinoma & 9 & & & & n.a. \\
\hline P11 & 68 & adenocarcinoma & 7 & + & + & & n.a. \\
\hline P12 & 80 & adenocarcinoma & 7 & + & + & + & n.a. \\
\hline P13 & 56 & adenocarcinoma & 7 & & + & & n.a. \\
\hline P14 & 74 & adenocarcinoma & 6 & + & + & + & n.a. \\
\hline \multirow[t]{2}{*}{ P15 } & 62 & adenocarcinoma & 8 & + & + & & n.a. \\
\hline & & & & $80.0 \%$ & $86.6 \%$ & $60 \%$ & $75 \%$ \\
\hline
\end{tabular}

Table 3. GT198 expression in human prostate tumor sections. Fifteen cases of human prostate tumor tissue FFPE sections were immunohistochemically stained with GT198 and analyzed for the presence of GT198+ blood vessels, myofibroblasts, and tumor cells. GT198 mutations were only analyzed in cases P1P4. The GT198 negative case is shaded in light blue. Percent of positive cases in total, percent of positive cases in each cell types, and percent of mutation positive cases are listed in blue. n.a., not analyzed. 


\begin{tabular}{|c|c|c|c|c|c|c|c|c|c|c|c|c|}
\hline \multicolumn{13}{|c|}{$\begin{array}{l}\text { Table 4. GT198 expression in bladder tumor slides } \\
\text { Overall GT198 positive rate }=76.4 \%(13 / 17)\end{array}$} \\
\hline $\begin{array}{l}\text { Case } \\
\text { No }\end{array}$ & Age & Sex & pTNM & $\begin{array}{l}\text { GT198+ } \\
\text { Stroma }\end{array}$ & $\begin{array}{l}\text { GT198+ } \\
\text { Tumor }\end{array}$ & $\begin{array}{l}\text { Angio- } \\
\text { genesis }\end{array}$ & $\begin{array}{c}\text { GT198 } \\
\text { Mutation }\end{array}$ & $\begin{array}{c}\text { Docetaxel } \\
\text { Treated }\end{array}$ & $\begin{array}{c}\text { PFS } \\
\text { Month }\end{array}$ & $\begin{array}{l}\text { Last } \\
\text { Status }\end{array}$ & $\begin{array}{l}\text { Progression } \\
\text { Recurrence }\end{array}$ & $\begin{array}{c}\text { Nodes } \\
\text { Removed }\end{array}$ \\
\hline $\mathrm{B} 1$ & 73 & $\mathrm{~F}$ & pTONO & ++ & & + & 2 & Yes & 33 & Alive & No & 0 of 9 \\
\hline $\mathrm{B} 2$ & 72 & $M$ & pT4aNO & + & + & & 0 & Yes & 19 & Dead & Liver, bone & 0 of 1 \\
\hline B3 & 40 & $\mathrm{~F}$ & pT3aNx & & + & & 1 & Yes & 12 & Dead & Peritoneum, lung & none \\
\hline B4 & 44 & $M$ & pTON3 & + & & + & 1 & Yes & 202 & Alive & No & 8 of 24 \\
\hline B5 & 59 & $M$ & pT3bN2 & + & + & + & 1 & Yes & 16 & Dead & Penis, scrotum & 4 of 4 \\
\hline B6 & 61 & $\mathrm{~F}$ & pT2aN2 & & & & 0 & Yes & 4 & Dead & Liver, lung & 6 of 8 \\
\hline B7 & 51 & $M$ & pTONO & ++ & & + & 0 & Yes & 182 & Alive & No & 0 of 11 \\
\hline B8 & 51 & $M$ & pT4aN1 & & ++ & & 0 & Yes & 9 & Dead & Pelvis & 4 of 11 \\
\hline B9 & 61 & $M$ & pT3aN1 & + & + & & 0 & Yes & 138 & Alive & No & 1 of 15 \\
\hline B10 & 53 & $\mathrm{~F}$ & pT2bN1 & ++ & & + & 4 & Yes & 23 & Dead & Liver & 1 of 3 \\
\hline B11 & 63 & $M$ & pT2bNO & & & & 0 & Yes & 5 & Dead & Unknown & 0 of 7 \\
\hline B12 & 47 & $M$ & pTisNx & + & + & + & 0 & Yes & 115 & Alive & No & none \\
\hline B13 & 64 & $\mathrm{~F}$ & pT3bNO & & ++ & & 3 & Yes & 5 & Dead & Retroperitoneum & none \\
\hline B14 & 70 & $M$ & pT1N1 & & & + & 0 & Yes & 68 & Dead & Liver, lung & 1 of 5 \\
\hline B15 & 57 & $\mathrm{~F}$ & pT2aN1 & & & & 0 & Yes & 45 & Dead & Groin nodes & 1 of 10 \\
\hline B16 & 75 & $M$ & pT3bN1 & & + & & n.a. & No & 19 & Dead & Unknown & 1 of 7 \\
\hline \multirow[t]{2}{*}{ B17 } & 45 & $M$ & pT2bN1 & + & & & n.a. & No & 132 & Alive & No & 1 of 14 \\
\hline & & & & $52.9 \%$ & $47.0 \%$ & $41.1 \%$ & $40.0 \%$ & & & & & \\
\hline
\end{tabular}

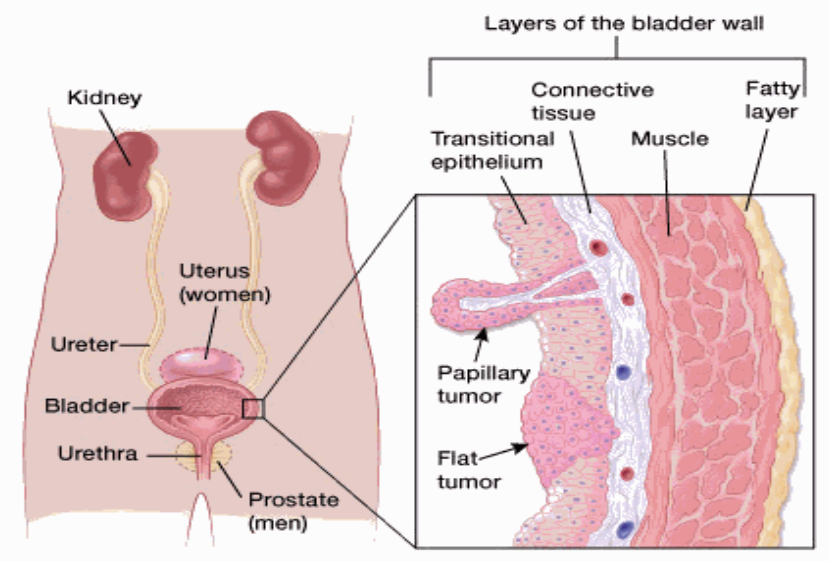

T0: No evidence of a primary tumor.

Ta: Noninvasive papillary carcinoma.

Tis: Carcinoma in situ (CIS) or a flat tumor.

T1: The tumor has spread to the connective tissue.

T2: The tumor has spread to the muscle of the bladder wall.

T3: The tumor has grown into the perivesical (fatty) tissue.

Figure credit: American Cancer Society

Table 4. GT198 expression in human bladder tumor sections. Seventeen cases of human bladder tumor FFPE sections with clinical information were immunohistochemically stained with GT198. The fifteen cases (B1-B15) were docetaxel-treated and were analyzed for the association of progression-free survival in Figure 4. The GT198 negative cases are shaded in light blue. Percent of positive cases in total, positive cases in cell types, angiogenesis, and mutation positive cases are listed in blue. pTNM, Pathological tumornode-metastasis staging; PFS, Progression-free survival; n.a., not analyzed. 


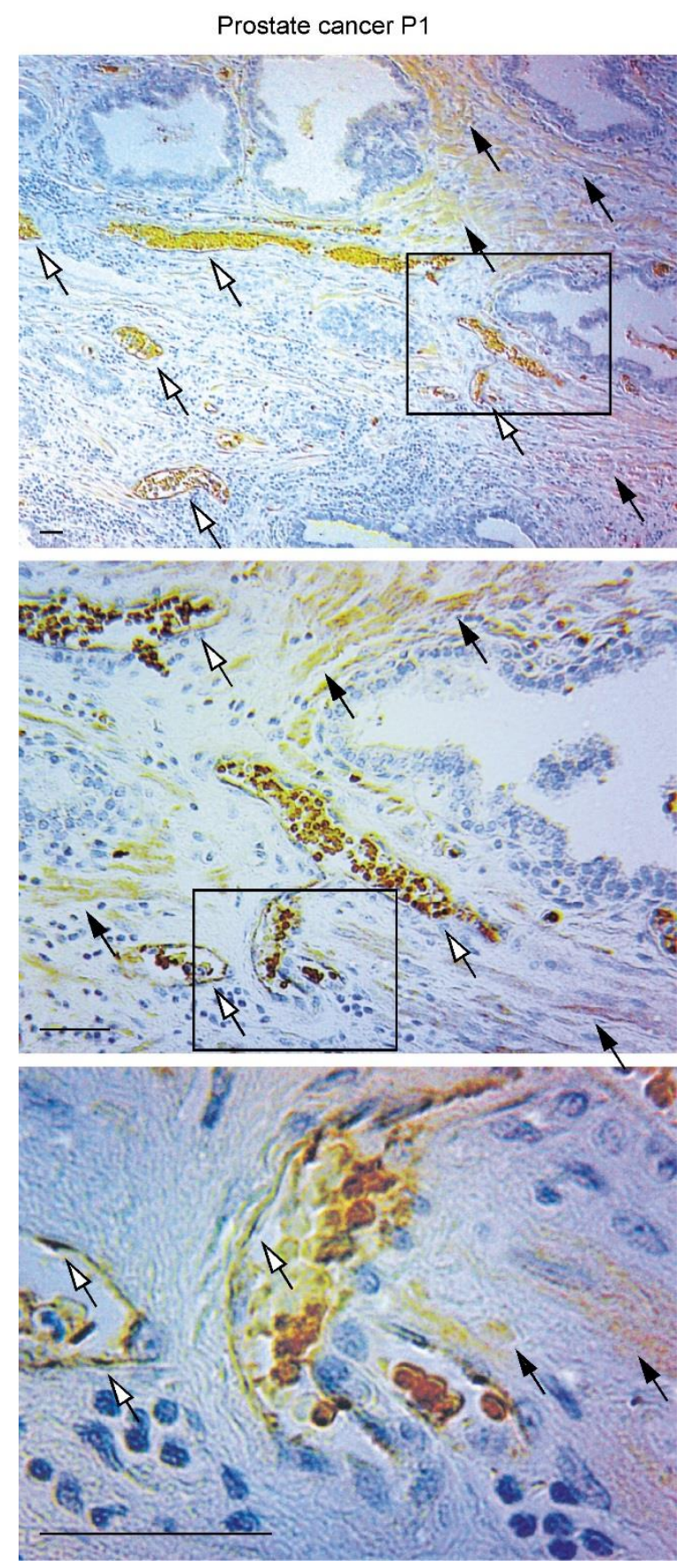

Supplemental Figure S1. Mutant tumor stroma of prostate cancer P1. Immunohistochemical staining of GT198 in prostate cancer case P1. The adjacent slide was sequencing analyzed to identify six GT198 somatic mutations (Figure 5). Boxed areas are serial enlarged below each panel. White arrows indicate GT198+ blood vessels. Black arrows indicate GT198 ${ }^{+}$myofibroblasts. Sections were counter-stained with hematoxylin. Scale bars $=100 \mu \mathrm{m}$. 


\section{METHODS}

\section{Study design and human prostate and bladder cancer samples}

Institutional Review Board (IRB) approval was obtained following institutional guidelines using de-identified human prostate and bladder cancer paraffin sections. Individual patient consent was not required. Formalin-fixed paraffin-embedded (FFPE) 5-micron sections of human prostate and bladder cancers were obtained from Indiana University School of Medicine, Indiana, IN; Medical College of Georgia, Augusta, GA; and Magee-Womens Hospital, University of Pittsburgh, Pittsburgh, PA. In addition, FFPE tumor tissue microarrays of prostate cancers were from Novus Biologicals, Centennial, CO and US Biomax Inc., Rockville, MD. Pathology diagnosis of all samples was verified through histological examination by pathologists. Prostate and bladder cancer tissue sections were analyzed by immunohistochemistry using anti-GT198. Selected four cases of prostate cancers (P1-P4) and fifteen cases of bladder cancers (B1-B15) were subjected to Sanger DNA sequencing analysis to identify somatic mutations in GT198 using serial cut adjacent sections.

\section{Immunohistochemistry}

Polyclonal antiserum against GT198 was previously prepared in rabbits (Covance, Denver, PA) (4,7). Affi-gel 10 affinity resins were covalently cross-linked to his-tagged GT198 protein as antigen for affinity purification of antiGT198 according to the manufacturer's protocol (Bio-Rad, Hercules, CA). FFPE tumor sections or tumor microarrays were deparaffinized and dehydrated through xylene and ethanol series, followed by antigen retrieval in $10 \mathrm{mM}$ sodium citrate buffer, $\mathrm{pH}$ 6.0, containing $0.05 \%$ Triton at $90^{\circ} \mathrm{C}$ for $20 \mathrm{~min}$. Anti-GT198 (1:150) was incubated at $4^{\circ} \mathrm{C}$ overnight. Antibody binding was detected using biotinylated anti-rabbit secondary antibody followed by detecting reagents (Abcam, Cambridge, MA). Sections were counterstained with hematoxylin. Data was graphed by scattergram using GraphPad Prism software.

\section{Mutation Analysis}

FFPE sections of prostate and bladder tumors were deparaffinized through xylene and $100 \%$ ethanol, and air dried. The adjacent sections were first stained by immunohistochemistry to locate the GT198 ${ }^{+}$stroma or tumor, and the positive areas $\left(0.5-1 \mathrm{~cm}^{2}\right)$ were removed using a new razor blade and transferred to the tube. Genomic DNA was isolated by DNeasy Tissue Kit reagents (Qiagen, Valencia, CA). DNA samples were PCR amplified and Sanger sequencing analyzed from both directions with repeats in two previously identified mutation hotspot sequences at 5'UTR to exon 2 (c.109C to c.103A) and at the exon 4-intron 4 junction (c.265C to c.337+116T) (6-8). The entire GT198 gene was not analyzed due to the fragmentation of DNA in FFPE sections. Primer pairs are: 5'UTR-F: 5'-ggggtcgctttgctcctccggaa-3', Intron 1-B: 5'-ctacggagagaaaggcagggga-3'; Intron 1-F: 5' -cagtgggtgaggaggtcggttga-3', Exon 2-B: 5'-agtccgtgttccegctgtaggt-3'; Exon 4-F: 5'-gtgagtgatgctgaccttcaagtc-3', Intron 4-B: 5'-tacacaaaagccgttagttatcct-3'. Nucleotide numbering is based on the cDNA reference sequence.

\section{Kaplan-Meier survival analysis}

The study consisted of 15 bladder cancer patients who underwent adjuvant docetaxel treatment at Indiana University, between June 1992 and June 2014. The longest postoperative follow-up duration was 17 years. The primary end point was progression-free survival without bladder tumor reoccurrence from the time of operation to the last day of follow-up. Progression-free survival was estimated by the Kaplan-Meier method. Hazard ratios (HRs) and $P$ values were calculated with the GraphPad Prism software using two-sided 0.05 significance level.

\section{Statistical analysis}

Statistical analyses were carried out using GraphPad Prism software. Scattergrams with means are presented using Gleason scores in $\mathrm{GT}_{198^{+}}$cases. $P$ values in scattergrams and bar graphs were calculated using unpaired two-tailed ttest. $P$ values in Kaplan-Meier curves were calculated by log-rank test. $* P<0.05$, ** $P<0.01$, $* * * P<0.001$; NS, not significant. A $P$ value of less than 0.05 is considered statistically significant. 


\section{REFERENCES}

1. Lopez-Beltran, A., Cheng, L., Montorsi, F., Scarpelli, M., Raspollini, M. R., and Montironi, R. (2017) Concomitant bladder cancer and prostate cancer: challenges and controversies. Nature reviews. Urology 14, 620-629

2. Singh, A., Kinoshita, Y., Rovito, P. M., Jr., Landas, S., Silberstein, J., Nsouli, I., Wang, C. Y., and Haas, G. P. (2008) Higher than expected association of clinical prostate and bladder cancers. The Journal of urology 179, S2-5

3. Heidegger, I., Oberaigner, W., Horninger, W., and Pichler, R. (2017) High incidence of clinically significant concomitant prostate cancer in patients undergoing radical cystectomy for bladder cancer: A 10-year single-center experience. Urologic oncology 35, 152 e $151-152$ e 155

4. Ko, L., Cardona, G. R., Henrion-Caude, A., and Chin, W. W. (2002) Identification and characterization of a tissue-specific coactivator, GT198, that interacts with the DNA-binding domains of nuclear receptors. Mol Cell Biol 22, 357-369

5. Satoh, T., Ishizuka, T., Tomaru, T., Yoshino, S., Nakajima, Y., Hashimoto, K., Shibusawa, N., Monden, T., Yamada, M., and Mori, M. (2009) Tat-binding protein-1 (TBP-1), an ATPase of $19 \mathrm{~S}$ regulatory particles of the 26S proteasome, enhances androgen receptor function in cooperation with TBP-1-interacting protein/Hop2. Endocrinology 150, 3283-3290

6. Peng, M., Zhang, H., Jaafar, L., Risinger, J. I., Huang, S., Mivechi, N. F., and Ko, L. (2013) Human ovarian cancer stroma contains luteinized theca cells harboring tumor suppressor gene GT198 mutations. J Biol Chem 288, 33387-33397

7. Yang, Z., Peng, M., Cheng, L., Jones, K., Maihle, N. J., Mivechi, N. F., and Ko, L. (2016) GT198 Expression Defines Mutant Tumor Stroma in Human Breast Cancer. Am J Pathol 186, 1340-1350

8. Peng, M., Yang, Z., Zhang, H., Jaafar, L., Wang, G., Liu, M., Flores-Rozas, H., Xu, J., Mivechi, N. F., and Ko, L. (2013) GT198 splice variants display dominant negative activities and are induced by inactivating mutations. Genes Cancer 4, 26-38
9. Chung, L. W., Chang, S. M., Bell, C., Zhau, H., Ro, J. Y., and von Eschenbach, A. C. (1988) Prostatic carcinogenesis evoked by cellular interaction. Environmental health perspectives 77, 23-28

10. Shiota, M., Fujimoto, N., Kashiwagi, E., and Eto, M. (2019) The Role of Nuclear Receptors in Prostate Cancer. Cells $\mathbf{8}$

11. Lombard, A. P., and Mudryj, M. (2015) The emerging role of the androgen receptor in bladder cancer. Endocrine-related cancer 22, R265-277

12. Risbridger, G. P., Davis, I. D., Birrell, S. N., and Tilley, W. D. (2010) Breast and prostate cancer: more similar than different. Nat Rev Cancer 10, 205-212

13. Chung, L. W., and Davies, R. (1996) Prostate epithelial differentiation is dictated by its surrounding stroma. Mol Biol Rep 23, 13-19

14. Enomoto, R., Kinebuchi, T., Sato, M., Yagi, H., Shibata, T., Kurumizaka, H., and Yokoyama, S. (2004) Positive role of the mammalian TBPIP/HOP2 protein in DMC1-mediated homologous pairing. J Biol Chem 279, 3526335272

15. Chi, P., San Filippo, J., Sehorn, M. G., Petukhova, G. V., and Sung, P. (2007) Bipartite stimulatory action of the Hop2-Mnd1 complex on the Rad51 recombinase. Genes Dev 21, 1747-1757

16. Cho, N. W., Dilley, R. L., Lampson, M. A., and Greenberg, R. A. (2014) Interchromosomal homology searches drive directional ALT telomere movement and synapsis. Cell 159, 108-121

17. Sansam, C. L., and Pezza, R. J. (2015) Connecting by breaking and repairing: mechanisms of DNA strand exchange in meiotic recombination. FEBS $J$ 282, 24442457

18. Zhao, W., and Sung, P. (2015) Significance of ligand interactions involving Hop2-Mnd1 and the RAD51 and DMC1 recombinases in homologous DNA repair and XX ovarian dysgenesis. Nucleic Acids Res 43, 4055-4066

19. Petukhova, G. V., Pezza, R. J., Vanevski, F., Ploquin, M., Masson, J. Y., and CameriniOtero, R. D. (2005) The Hop2 and Mnd1 proteins act in concert with Rad51 and Dmc1 in meiotic recombination. Nat Struct Mol Biol 12, 449-453 
20. Cheng, H. H. (2018) The resounding effect of DNA repair deficiency in prostate cancer. Urologic oncology 36, 385-388

21. Peng, M., Bakker, J. L., DiCioccio, R. A., Gille, J. J. P., Zhao, H., Odunsi, K., Sucheston, L., Jaafar, L., Mivechi, N. F., Waisfisz, Q., and Ko, L. (2013) Inactivating mutations in GT198 in familial and early-onset breast and ovarian cancers. Genes Cancer 4, 15-25

22. Rommens, J. M., Durocher, F., McArthur, J., Tonin, P., LeBlanc, J. F., Allen, T., Samson, C., Ferri, L., Narod, S., Morgan, K., and et al. (1995) Generation of a transcription map at the HSD17B locus centromeric to BRCA1 at 17q21. Genomics 28, 530-542

23. Lange, E. M., Robbins, C. M., Gillanders, E. M., Zheng, S. L., Xu, J., Wang, Y., White, K. A., Chang, B. L., Ho, L. A., Trent, J. M., Carpten, J. D., Isaacs, W. B., and Cooney, K. A. (2007) Fine-mapping the putative chromosome 17q21-22 prostate cancer susceptibility gene to a $10 \mathrm{cM}$ region based on linkage analysis. Human genetics 121, 49-55

24. Gao, X., Zacharek, A., Salkowski, A., Grignon, D. J., Sakr, W., Porter, A. T., and Honn, K. V. (1995) Loss of heterozygosity of the BRCA1 and other loci on chromosome $17 \mathrm{q}$ in human prostate cancer. Cancer Res 55, 1002-1005

25. Uchida, T., Wang, C., Sato, T., Gao, J., Takashima, R., Irie, A., Ohori, M., and Koshiba, K. (1999) BRCA1 gene mutation and loss of heterozygosity on chromosome $17 \mathrm{q} 21$ in primary prostate cancer. Int J Cancer $\mathbf{8 4}, 19$ 23

26. Xu, J., Dimitrov, L., Chang, B. L., Adams, T. S., Turner, A. R., Meyers, D. A., Eeles, R. A., Easton, D. F., Foulkes, W. D., Simard, J., Giles, G. G., Hopper, J. L., Mahle, L., Moller, P., Bishop, T., Evans, C., Edwards, S., Meitz, J., Bullock, S., Hope, Q., Hsieh, C. L., Halpern, J., Balise, R. N., Oakley-Girvan, I., Whittemore, A. S., Ewing, C. M., Gielzak, M., Isaacs, S. D., Walsh, P. C., Wiley, K. E., Isaacs, W. B., Thibodeau, S. N., McDonnell, S. K., Cunningham, J. M., Zarfas, K. E., Hebbring, S., Schaid, D. J., Friedrichsen, D. M., Deutsch, K., Kolb, S., Badzioch, M., Jarvik, G. P., Janer, M., Hood, L., Ostrander, E. A., Stanford, J. L., Lange, E. M., Beebe-Dimmer, J. L., Mohai, C. E., Cooney, K. A., Ikonen, T., Baffoe-Bonnie, A., Fredriksson, H., Matikainen, M. P.,
Tammela, T., Bailey-Wilson, J., Schleutker, J., Maier, C., Herkommer, K., Hoegel, J. J., Vogel, W., Paiss, T., Wiklund, F., Emanuelsson, M., Stenman, E., Jonsson, B. A., Gronberg, H., Camp, N. J., Farnham, J., Cannon-Albright, L. A., Seminara, D., and Consortium, A. (2005) A combined genomewide linkage scan of 1,233 families for prostate cancer-susceptibility genes conducted by the international consortium for prostate cancer genetics. Am J Hum Genet 77, 219-229

27. Dai, Q., Deubler, D. A., Maxwell, T. M., Zhu, X. L., Cui, J., Rohr, L. R., Stephenson, R. A., and Brothman, A. R. (2001) A common deletion at chromosomal region $17 \mathrm{q} 21$ in sporadic prostate tumors distal to BRCA1. Genomics 71, 324-329

28. Gao, X., Zacharek, A., Grignon, D. J., Sakr, W., Powell, I. J., Porter, A. T., and Honn, K. V. (1995) Localization of potential tumor suppressor loci to a $<2 \mathrm{Mb}$ region on chromosome $17 \mathrm{q}$ in human prostate cancer. Oncogene 11, 1241-1247

29. Cooney, K. A. (2017) Inherited Predisposition to Prostate Cancer: From Gene Discovery to Clinical Impact. Transactions of the American Clinical and Climatological Association 128, 14-23

30. Hemminki, K., Forsti, A., and Chen, B. (2010) Breast and prostate cancer: familial associations. Nat Rev Cancer 10, 523

31. Schubert, S., Ripperger, T., Rood, M., Petkidis, A., Hofmann, W., Frye-Boukhriss, H., Tauscher, M., Auber, B., Hille-Betz, U., Illig, T., Schlegelberger, B., and Steinemann, D. (2017) GT198 (PSMC3IP) germline variants in early-onset breast cancer patients from hereditary breast and ovarian cancer families. Genes Cancer 8, 472-483

32. Zangen, D., Kaufman, Y., Zeligson, S., Perlberg, S., Fridman, H., Kanaan, M., Abdulhadi-Atwan, M., Abu Libdeh, A., Gussow, A., Kisslov, I., Carmel, L., Renbaum, P., and Levy-Lahad, E. (2011) XX ovarian dysgenesis is caused by a PSMC3IP/HOP2 mutation that abolishes coactivation of estrogen-driven transcription. Am J Hum Genet 89, 572-579

33. Zhang, L., Wang, Y., Rashid, M. H., Liu, M., Angara, K., Mivechi, N. F., Maihle, N. J., Arbab, A. S., and Ko, L. (2017) Malignant 
pericytes expressing GT198 give rise to tumor cells through angiogenesis. Oncotarget 8, 51591-51607

34. Cunha, G. R., Hayward, S. W., and Wang, Y. Z. (2002) Role of stroma in carcinogenesis of the prostate. Differentiation 70, 473-485

35. Taylor, R. A., and Risbridger, G. P. (2008) Prostatic tumor stroma: a key player in cancer progression. Curr Cancer Drug Targets 8, 490497

36. Sasaki, T., Franco, O. E., and Hayward, S. W. (2017) Interaction of prostate carcinomaassociated fibroblasts with human epithelial cell lines in vivo. Differentiation 96, 40-48

37. De Wever, O., Demetter, P., Mareel, M., and Bracke, M. (2008) Stromal myofibroblasts are drivers of invasive cancer growth. Int $J$ Cancer 123, 2229-2238

38. Ko, L. (2019) Human solid cancer decoded. Zenodo http://doi.org/10.5281/zenodo.3236836

39. Yang, Z., Gurvich, V. J., Gupta, M. L., Mivechi, N. F., and Ko, L. (2019) Oncoprotein GT198 is a direct target of taxol. BioRxiv, https://doi.org/10.1101/675579

40. Ghosh, A., Stewart, D., and Matlashewski, G. (2004) Regulation of human p53 activity and cell localization by alternative splicing. Mol Cell Biol 24, 7987-7997

41. Green, D. R., and Kroemer, G. (2009) Cytoplasmic functions of the tumour suppressor p53. Nature 458, 1127-1130

42. Khoury, M. P., and Bourdon, J. C. (2011) p53 Isoforms: An Intracellular Microprocessor? Genes Cancer 2, 453-465

43. Armulik, A., Genove, G., and Betsholtz, C. (2011) Pericytes: developmental, physiological, and pathological perspectives, problems, and promises. Dev Cell 21, 193-215 